\title{
GENDER, FEMINIST ACTIVISM AND CONSERVATISM IN LATIN AMERICA: AN INTERVIEW WITH FLÁVIA BIROLI, FLAVIA FREIDENBERG E VERÓNICA GAGO'
}

\author{
By Marcia Candido, Simone Gomes and Talita Tanscheit ${ }^{2}$
}

Portuguese and Spanish translations and editions: Marcia Candido, Simone Gomes and Talita

Tanscheit

English version: Karine Belarmino, Clara Faulhaber, Ana Beatriz Martins, Lorena Miguel e Isadora Vianna Sento-Sé ${ }^{3}$

\begin{abstract}
This interview discusses the challenges to gender studies and feminist movements facing the radicalization of the right-wing in Latin America. To this purpose, it selects three interlocutors of academic legitimacy in the region: Flávia Biroli, Flávia Freidenberg e Verónica Gago. The conversation is structured around two central points: on the one hand, it debates the recent conservative reactions and public spaces changes resulting from women's mobilization for rights and in defense of democracy; on the other hand, it confronts the definition that "gender studies" constitute a specific theme of Social Sciences, describing feminist perspectives as transformative biases that are essential to a broad understanding of political and social phenomena.
\end{abstract}

Marcia Candido, Simone Gomes and Talita Tanscheit: Thank you for accepting the interview. The purpose of this dossier is to discuss the direction

\footnotetext{
${ }^{1}$ See interviews resume at the end of text, p. 83

2 Marcia Candido is a PhD student in Political Science at the Institute of Social and Political Studies of the State University of Rio de Janeiro (Iesp-Uerj) and receives a scholarship from Coordination for the Improvement of Higher Education Personnel (Capes). E-mail: marciarangelcandido@gmail.com

Simone Gomes is Professor at the Department of Sociology and Political Science at the Federal University of Pelotas (UFPel) and the Postgraduate Program in Sociology at the same institution. E-mail: s.ribeirogomes@gmail.com

Talita Tanscheit is a PhD student in Political Science at the Institute of Social and Political Studies of the State University of Rio de Janeiro (Iesp-Uerj) and Substitute Professor at the Department of Political Science of the Federal University of Rio de Janeiro (Ifcs-Ufrj). E-mail: talitastt@gmail.com

${ }^{3}$ Karine Belarmino is a PhD student in Political Science at University of Minnesota - MN, USA. E-mail: belar007@umn.edu

Clara Faulhaber is master in Social Sciense at the State University of Rio de Janeiro (PPCIS/UERJ). Email: clarafaulhaber@gmail.com

Ana Beatriz Martins is PhD in Sociology and Researcher at the University of Sydney - Sydney, Au. Email: ana.martins@sydney.edu.au

Lorena Miguel is a PhD student in Sociology at Pontifical Catholic University of Rio de Janeiro (PUCRio). E-mail: lorenamsmiguel@gmail.com

Isadora Vianna Sento-Sé is a PhD student in Social Sciences at the State University of Rio de Janeiro (PPCIS/UERJ). E-mail: isadorasentose@gmail.com
} 
of feminism in Latin America and the threats posed by the advance of conservatism around the world. We chose the three of you because we consider you unique references in these matters, and because we identify similarities in your trajectories. Thus, the first question we raise concerns your intellectual choices. The inclusion in the field of gender studies does not seem to have been the first option in your career paths. What events motivated your deepening in the theme?

Flávia Biroli: I have an atypical trajectory, my bachelor's degree is in Journalism, my master's and PhD degrees are in History, and, since 2003, my work has been in the Political Science area, as a professor in the Political Science Institute of the University of Brasilia (IPOL-UnB) and integrated academically in this area not only as a professor, but with my research, publications, dialogues. My main research theme was communication and politics until 2006. And it was through it that I came to gender studies, when I started working with a colleague of the IPOL-UnB, Luis Felipe Miguel, researching about women in politics and in the political news, within the debate about female political under-representation. I had to look at my resume to remind myself of the dates and that made me realize that, since 2009, most of my publications was on women, gender and politics. Initially, media and political representation, in partnership with Luis Felipe, were the main themes. Then the concept of autonomy in the feminist theoretical debate, increasingly connected to the debate about sexual division of labor and care. Possibly, what matters most is that when I started working on gender and political research, my understanding of the whole debate about democracy quickly shifted. The fact that feminist theories make visible the exclusions that can only be explained by the connection between the categories mobilized by research, the gender hierarchies in everyday life and the gender hierarchies in politics, is their greatest strength, in my understanding. Another point is that feminist struggles and theories are reciprocally constituted. In my case, the involvement with feminism came as I immersed into theoretical debate and research. 
Flávia Freidenberg: For many years, I understood political science as a discipline outside the feminist debates. I did not have a gender perspective from which to approach the study of power and the political system and repeatedly reiterated that science should be indifferent to ideological debates (ignoring that, saying this, it already expressed an ideology). I was not interested in these themes and did not believe that they were necessary studies for the development of scientific knowledge. In the beginning of my career I was unaware and ignored gender inequalities, and I did not consider them fundamental to my education, the readings I had to do or my research. During this entire stage, I was very naive in believing that these issues related to gender inequalities and the role of women in society - were the property of sociology or, specifically, of gender studies.

I graduated from a school where the analyses about power and the functioning of the political system gave little attention to the presence or absence of women. Politics was analyzed as a "men's thing" and, fundamentally, from an androcentric perspective. There were not female authors, or at least we did not read them; my female professors were few and most were in secondary positions (such as teacher assistants of male professors). In this sense, it took me a while to realize that both "science" and "politics" could not escape the articulation of the asymmetrically constructed social order between men and women.

Basically, my change was a change of "lenses" (of glasses), of perspective on the way knowledge is approached and practiced. My own personal experiences with glass ceiling in university institutions (and even my own concrete ceilings or self-limitations of what I was able to do), for example, had an important impact on my way of thinking and practice political science. Also, the fact that several of my colleagues (men and women) had this perspective helped me to "remove the veil" that I had on my eyes that prevented me from seeing with gendered glasses. Nowadays, I continue to experience a process of change, deconstruction and daily unlearning, increasingly interested in discovering and practicing a feminist political science.

I feel increasingly comfortable with adopting positions connected to "feminist neo-institutionalism", as authors such as Jay Lovenduski or Fiona Mackay have pointed out, to better understand power relations and the links 
between actors. It is not a matter of studying problems of political representation (as a gender political science would do), but of studying this representation thinking about the way in which gender inequalities suppose asymmetries in the access and exercise of political power. I believe that in this space we have a lot to do as comparative researchers to think about actions (and policies) that contribute to "degender" public institutions and decisions.

Verónica Gago: My theoretical concerns and research have been centered from the beginning on the debate about the forms of work in contemporary capitalism. Since then, without a doubt, the whole theme related to what is known as the "feminization of work" and migrant work has had a vital importance for me, in order to understand more broadly the sequences of historical struggles that produce antagonism and force in different moments the occurrence of social ruptures and, in particular, the confrontation of exploitative relations. This is inevitable, in my opinion, thinking about Latin America, and from Argentina in particular, when it comes to situating the transnational dimension both of the processes of struggle, of their bodies and territories in conflict, and of the renewed imperial forms. The debates on neoliberalism that I have been entering, in turn, and in particular those that seem to me to be more inspiring in conceptual terms, make the production of subjectivity the key. Following the line explored by Michel Foucault, but also by the feminist and post-marxist debate, for me it is inevitable to arrive at these issues that they call "gender", but in a specific way: through those who think the articulation between capitalism and patriarchy as the specific logic of modern-colonial valorization. In our continent we have a very rich arsenal of concepts and experiences, of surveys and theorizations that arm a concrete way of persevering and intervening in these issues. That is to say, from Latin America we cannot fail to situate ourselves in what has "not" been historically recognized as work and in this the dimensions of race and gender are constitutive vectors of what we can problematize, of what permanently appears as a space of exploitation, subordination and, in turn, of revolt and collective innovation.

But my cognitive desire, to call it somehow, is nourished by my political militancy and by my work at the independent publisher Tinta Limón. I have 
been involved in political processes since I was a student at university, to be part of autonomous militant research experiments and in relation to various social movements, which since the beginning of this century have repeatedly challenged the political legitimacy of neoliberalism. I soon committed myself more directly to feminist struggles, which also led me to reformulate my work concerns in this perspective, yet it was something I had already been working on, reading and researching.

In this way I want to say two things: that the orientation of my theoretical concerns has always developed within processes of political militancy and, therefore, that feminist struggles have been a practical inspiration in the way these investigations have unfolded.

I feel some lines of continuity over time. For example, the methodological and political question about the situated character of thought and, therefore, of its corporal materiality. In this sense, a situated thinking is inevitably a feminist thinking. Because if something has taught us the history of struggles, of their conquests and failures, it is that the power of thought always has a body. And that this body is a constant and collective composition (even when it is individual), which reassembles experiences, expectations, resources, trajectories and memories. A situated thinking is inevitably partial. Partiality does not entail a small part, a fragment or a splinter. But it is a flap in a do-it-yourself, a specific assembly. As such, it functions as an entry point, a perspective, which singularizes an experience. These elements have always inspired me to think feminist political theory because they reveal the character of the masculine as universal that is at the origins of the entire political "order". I believe that because of these issues I have specialized "only" in gender and, therefore, my theoretical and political interlocutions are also diverse. But the feminist perspective, as we know, is not only synonymous with the theme of gender, but an epistemic and political way of approaching all the practices, the focuses of experiences, the dynamics of insubordination and the ways of elaborating knowledge.

Candido, Gomes and Tanscheit: In addition to poor peer legitimacy, gender studies have been one of the main targets for aggression and censorship by conservative political actors. Intending to harden the interventions of the new 
right-wing governments in public universities, what are the main challenges for teachers involved with feminist movements? Can you comment on what the notion of "gender ideology" in your respective countries means and how it is used as an instrument to persecute researchers?

Biroli: We have had a hard time getting colleagues to understand that gender studies are not studies about women or about specific issues: they are about democracy and its functioning, about power relations and the hierarchies that organize access to resources and selective guarantees for people. The conservative reaction seems to have understood this. They fight gender studies for their potential to displace naturalized hierarchies, to broaden public debate about oppressions and forms of exploitation that underlie privileges. Gender studies indeed affect precisely for this reason "families", "order" and "nature" as hierarchical and privileging devices of some, to the detriment of others (women in this case). Do you know what is this so-called nature they miss so much? It is a disciplinary social order, which has the free work of women and the control of their bodies and reproductive capacity as a fundamental basis. The campaign against the so-called "gender ideology" is transnational and has relied on organizations that raise funds and openly state their intentions: to focus on the state in national contexts and on international organizations, the UN system more specifically, in order to stop an agenda that produces effects and shifts gender hierarchies. They are particularly concerned about the socialization of children. There is a relevant generational question. They want to protect themselves from change, but they hold the banner of child protection as a way to mobilize audiences in a time of transformation and insecurity. They also reproduce a narrative: that feminism was once "good" when it fought for women's right to wage and vote. But since the middle of the twentieth century - and locating in Simone de Beauvoir the point of origin has been taken over by radicalisms. And women would have even forgotten what they are! Above all, they do not accept the denaturalization of roles based on biological sex.

Freidenberg: Gender ideology does not exist as such. On the contrary, I usually think of it as a mechanism of the conservative sectors (inside and 
outside academia) to reproduce a crack (a division) against the people who defend equality between men and women and those who do not defend it. Gender Ideology is part of a strategy to neutralize movements that seek to expand rights. In the academic space in which I currently develop my profession, I do not feel especially threatened by defending these positions, by writing and researching women's political participation and representation, or by assuming an active commitment to defending women's political and electoral rights. I am sometimes asked disparaging questions or comments, but I understand that my task is to make pedagogy and add more and more voices to the struggle for rights.

In Mexico, the conservative actors are active, promoting "their" gender ideology, but unless I know, or can record in an express and direct way, they are not pursuing social science researchers who promote the defense of women's rights. Nevertheless, there are many obstacles, [gender] research is not yet part of the mainstream of the discipline, and dialogues generally remain between women. Political Science remains conservative (as Jay Lovenduski point out); it has resisted feminist themes and approaches and has been built on conceptual, theoretical and methodological notions that involve a deep bias of male gender, reproducing "generified symbols of expertise" (as Johanna Kantola called in her studies of Finland) in relation to who is the specialist, which themes and who are marginal in the discipline ${ }^{4}$.

In reality, women remain under-represented as professors in university departments and their participation decreases as positions of power in academic management progress ${ }^{5}$. They are also invisible in the master conferences of congresses, in the references and citations to their academic publications, in the editorial committees or technical councils of the professional associations of the discipline, and even in the entries of Wikipedia

\footnotetext{
${ }^{4}$ KANTOLA, Johanna. (2008). "Why Do All the Women Disappear? Gendering Processes in a Political Science”. Department. Gender, Work and Organization, vol.15, n.2, mar. 2008.

KANTOLA, Johanna. (2015). "Political Science as a Gendered Discipline in Finland". European Political Science, n.14, p.79-86.

5 Overviews of diversity in the political science professors workforce in national contexts are still rare. To see a survey on the Brazilian scenario, consult: CANDIDO, Marcia. FERES JÚNIOR, João. CAMPOS, Luiz Augusto. (2019, no prelo). "Desigualdades na elite da Ciência Política Brasileira". Civitas - Revista de Ciências Sociais. Dossiê - História, desenvolvimento e ensino da Ciência Politica. In Latin America, more generally, consult: CARPIUC, Cecília. (2016). "Women and Diversity in Latin American Political Science”. European Political Science.
} 
profiles, where the category "political scientist" hardly appears and the presence of Latin American scientists is marginal6.

Gago: We are living in a moment of counter-offensive: that is, of reaction to the force demonstrated by feminisms in the region. It is important to reschedule the sequence: the counter-offensive responds to an offensive, to a previous movement. This supposes locating the emergence of feminisms in relation to the subsequent fascist turn in the region and at the global level. Two considerations come from this. In methodological terms: to locate the force of feminisms in the first place, as a constituent force. In political terms: to affirm that feminisms set in motion a threat to the established powers and activate a dynamic of disobediences that they try to contain, opposing forms of repression, discipline and control on various scales. The counter-attack is a call to order and its aggressiveness is measured in relation to the perception of threat to what is being responded to. For this reason, the ferocious counteroffensive unleashed on feminisms gives us a reverse reading of the force of insubordination that has been perceived as already happening and, in turn, with the possibility of radicalization.

Through the concept of "gender ideology" today an authentic crusade headed by the chaotic church and other religious fundamentalisms against feminist destabilization is synthesized. This "crusade", after being elaborated in the domes of theological power, seeks to fabricate its "social movement" to dispute body to body in territories that have been touched by feminist struggles. In Argentina, there is a point of intensification of this conservative counter-offensive and it is the "green wave" (that is, a real mobilization of the masses) in favor of the legalization of abortion, which during 2018 flooded the streets and dispersed its impact on a worldwide level.

The religious arguments here have tried to draw a class distinction that would justify that poor women have no more option than to be Catholic and

\footnotetext{
${ }^{6}$ For data on the under-representation of women among the references in political science, see, for example, HARDT, Heidi. et al. (2019). "The Gender Readings Gap in Political Science Graduate Training”. The Journal of Politics. In the case of professional associations, consult ABU-LABAN, Yasmeen. SAWER, Marian. ST-LAURENT, Mathieu. (2018). IPSA Gender and Diversity Monitoring Report. Available in: https://www.ipsa.org/sites/default/ files/2018-

06/IPSA\%20Gender\%20and\%20Diversity\%20Monitoring\%20Report\%202017_FINAL\%20\%28web\%20v ersion\%29.pdf
} 
conservative, because they only have motherhood as an option. In this way, abortion (that is, deciding on desire, motherhood, and life itself) tries to be reduced to an eccentric gesture of the middle and upper classes (which, of course, can put different economic resources at stake). The "classist" argument, which certainly exists in terms of differentiated possibilities to access safe abortion, is inverted: it starts to function as a justification of clandestinity. The right to decide, for the Church, must remain thus far from the popular neighborhoods. The "gender ideology", through its spokespersons, proclaims itself as antineoliberal. But the "gender ideology" proposes that neoliberalism must be fought through a return to the family, to disciplined work as the sole provider of dignity, and compulsory motherhood as the guarantor of women's place.

Neoliberalism, thus, is defined as a policy of a subjective mode of pure disintegration of the family order and work, that is, patriarchal. That this order is patriarchal, however, is not problematized. We arrive at a kind of logical contradiction: can antineoliberalism be sustained in a patriarchal order, whose biological and colonial structure is indissoluble? This is exactly what feminisms have made evident in their massive radicalization: there is no neoliberal capitalism without a patriarchal and colonial order.

Together with the ecclesial counter-offensive, we are seeing an economic counter-offensive deepened. In this articulation we see a fundamental role of current neoliberalism: the deepening of the crisis of social reproduction that is sustained by an increase in female labour, which has replaced public infrastructures and ends up implied in dynamics of overexploitation. The privatization of public services or the restriction of their scope means that these tasks (health, care, food, etc.) must be supplied by women and feminized bodies as an unpaid and obligatory task. Several authors have highlighted the moralizing use propagated with this same reproductive crisis. Here a fundamental key emerges: the bases of convergence between neoliberalism and conservatism.

How does this work in the adjustment against university and research institutions? There is a generalized cut in funding (let's think that Mauricio Macri's government last year eliminated 13 Ministries, among them the Science and Technology Ministry). But undoubtedly, in terms of research, the 
most affected areas are those of the social sciences, and even more remarkably those linked to gender studies. This is accompanied by media campaigns where these research topics are ridiculed and treated as "superfluous" or useless. At the same time, there is an attempt to reconcile feminism and neoliberalism on the side of NGO proposals and debt offerings (via microcredit and bank loans), as a way to translate and neutralize the more disobedient dimension of mobilized feminisms.

Candido, Gomes and Tanscheit: Concerning women's lives, several Latin American countries are leaders in violence against the female gender. In addition to issues of private life, with severe rates of internal aggression to the family, women's political participation - institutionally or in social movements is often beset by oppression. How has feminist research contributed to elucidating these dynamics?

Biroli: Feminist research has explicitly made these violences to be seen as political problems. This is a fundamental point. Naturalized everyday violence has also been historically depoliticized: "women don't respect themselves", "what was she expecting, acting the way she did", "women don't want to participate in politics". Note that the stereotypes that justify aggression organize at the same time everyday violence, barriers to equal participation, and the systematic withdrawal of resources that have allowed women to effectively address the norms. Another important point is that feminist studies, even those with an institutionalist perspective, analyze the relationship between institutions and informal practices that reproduce inequalities and barriers to women's participation. And they do so by validating the experiences of women, of diverse women, in these relationships. This unveiling of informal practices of marginalization and oppression is due to the construction of new analytical categories, which allow us to see new problems, insofar as it takes into account half of the population that has been refused to be a political subject and subject of knowledge, historically, by others. 
Freidenberg: In most Latin American countries, gender-based political violence has been one of the undesirable consequences of electoral policy reforms carried out in the region to increase women's political participation. Since 1991, the axis countries have made at least 37 electoral reforms to force political parties to place women in democratic institutions. The number of women in legislative chambers in Latin America and the Caribbean has increased from 9\% to almost 30\% in 2018 (according to ECLAC data) ${ }^{7}$

Research in Political Science has contributed to identify, visualize and conceptualize this violence. In Mexico, a number of debates have been held on this subject. Studies such as those of Mona Lenna Krook, Juliana Restrepo, María del Carmen Alanis or Jennifer Piscopo, together with those of the electoral authorities (judges and officials), were fundamental in identifying what political violence against women is, precisely because they are women. Also intergovernmental agencies (such as Inter-American Commission of Women of OAS or United Nations Entity for Gender Equality and the Empowerment of Women), Women's Collectives (such as Red de Mujeres en Plural, REPARE and Asociación de Mujeres Guerrerenses AC) together with civil society organizations, contributed to the identification of violent practices and simulations that the parties carry out against women.

Gago: Feminist investigations have put into play another economy of visibility for violence. A central point of the mobilizations of these years, especially with the political exercise of the strike, is to construct a feminist diagnosis of the intertwining of the different forms of violence and to spread it in all spaces: educational, political, institutional, community, etc.

In this sense, the reconceptualization of macho violence has been key for the feminist movement in recent years in two ways: first, by pluralising its definition - we stop talking "only" about violence against women and feminised bodies and put it in relation to a set of violences without which it cannot be explained, and even less understood in relation to its historical increase. Talking about violence from feminicide and homicide of transgender people

7 Available on: https://oig.cepal.org/pt/indicadores/poder-legislativo-porcentagem-mulheres-noorgao-legislativo-nacional-camara-baixa-ou 
locates them as its culminating point, but imposes a challenge: not to close ourselves in there, in its necropolitical accounting.

In this way, dealing with the pluralization of violence is strategic: it is a concrete form of connection that produces intelligibility and, therefore, allows a displacement of the totalizing figure of the victim. Pluralizing is not just a quantification, a list, of violence. It is something much denser: it is a way of mapping its simultaneity and its interrelationship. It is to connect exploded homes to the devastated lands of agrobusiness, to wage differences and invisibilized domestic work; to link the violence of adjustment and crisis with the ways in which they are faced from a feminized protagonism of popular economies; and to relate all this to financial exploitation by public and private indebtedness; to tie the forms of discipline of disobedience to the hands of the smooth and earthly repression of the State and the persecution of migrant movements, also in the way in which the poorest women are imprisoned, criminalizing subsistence economies and those who practice abortion, with the racist mark of each one of these acts of violence. Nothing in this network of violence is obvious: to trace the ways of its connection is to produce meaning, because it makes visible the machinery of exploitation and extraction of value that implies ever greater thresholds of violence and that has a differentiated (and therefore strategic) impact on the feminized bodies.

Candido, Gomes and Tanscheit: Remarkably, both academic production and feminist activism have been renewed in recent years. What continuities and ruptures do you observe in the production of current generations compared to previous ones? And the differences in militancy in the streets? How to reconcile these generations and their acting strategies?

Biroli: Feminisms became more capillarized in the 2000s. There are some aspects that I think are quite relevant in this capillarization: the multiplication of organizations, appearing more in the form of collectives than the movements we knew (and, precisely because of that, they do not meet same organizational standards); the feminist agenda is present in different spaces and is therefore mobilized in an even more plural and different form; the gains in legitimacy from feminist perspectives have sparked reactions that seek to challenge 
precisely what has been most effective, namely that the foundations of the gender equality agenda have become popular and even appear to be a feature of the public - public as a multiplicity and conflicts - in our time. The fact that this capillarization may have been potentiated by the institutional action of feminists who have been active for a few decades - this is a hypothesis that I find plausible, thinking of international organizations, in incorporating the agenda into national institutional contexts - does not lead feminists who have thus come to identify and act together in recent years and identifies to recognize as relevant the institutional action and its means and spaces. I think there is a lot of power in today's feminisms, but it would be important to discuss to what extent the diagnosis of weakening democracies and the risks it poses for women has turned into strategic action to build democracies. And what does that mean? In my perspective, it means strengthening political parties by modifying them. To build broad foundations for the political struggle for rights and for more egalitarian societies in which caring relations are at the heart of political concerns, which necessarily implies criticism of neoliberal capitalism. But there is not and there will be no political unity of action - and that is not the problem. Feminism has always been a daily battle that unfolds into strategic actions to modify institutions and build rights. It is in these strategies that generational differences may become more visible because those that have been active the longest have perceptions of the struggle in institutional spaces that may be quite distinct from those among the new collectives. The most successful actions, in my view, are those that have been able to connect the power of this daily fight to the organization to focus on institutions, stop violence and advance rights. It would be necessary to analyze on a case-by-case basis, but are not these precisely actions that have produced, in their construction and political course, interaction, dialogue, joint action of different generations, the search for institutional alternatives? Is this not what happened in the fight for abortion rights in Argentina? In the mobilization against PL 5069 and in the construction of \#NotHim in Brazil?

Freidenberg: For me, it is not very easy to compare moments and phases because my experience is recent. Our professors (Line Barreiro or Alejandra Massolo) say that this is a historic moment of mobilization in the streets 
(Brazil, Argentina, Chile) and also of expansion of legal rights (Mexico, Costa Rica, Bolivia or Ecuador). They also warn us about the need to continue working so that the conquests are maintained and enduring, because the waves of expansion of rights are always accompanied by offensives that seek to eliminate these same rights.

Gago: The massive dimension has a lot to do with the intergenerational composition of the movement. We see the convergence of different layers or strata of militancy and debates that are updated as part of political transversality.

For a long time feminism has been understood in its most institutional and/or academic variant, historically dissociated from the processes of popular confluence. What we see today is that feminism has become a presence and a concrete force in a multiplicity of spaces and territories. There are fundamental genealogical lines that have made this current expansion possible. In Argentina, we highlight four: (1) the history of the struggle for human rights since the 1970s, led by the Mothers and Grandparents of Plaza de Mayo; (2) the more than three decades of the National Meeting of Women (now plurinational of women, lesbians, trans and transvestites); (3) the irruption of the piquetero movement (of unemployed workers), of a protagonism also feminized in face of the social crisis of the beginning of the century; (4) and a long history of a movement of sexual dissent ranging from the inheritance of the Homosexual Liberation Front (HLF) of the 1970s to lesbian militancy for autonomous access to abortion and trans, transvestite, intersex and transgender activism, which revolutionized the bodies and subjectivities of feminism against biological limits.

The transversality achieved through the organization of the strike updates these historical lines and projects them into a mass feminism, rooted in the concrete struggles of the workers of the popular economy, the migrants, the cooperativists, the defenders of the territory, the precarious, the new generations of sexual dissidents, the housewives who renounce confinement, the struggle for the right to abortion, which is the expanded struggle for corporal autonomy, the mobilized students, those who denounce pesticides, 
the sex workers. They place a common horizon in organizational terms that works as a practical catalyst.

The powerful thing is that the integration of this multiplicity of conflicts redefines the dimension of the masses from practices and struggles historically defined as "minority". With this, the opposition between the minority and the majority shifts: the minority assumes a mass scale as a vector of radicalization within a composition that continues to expand. In this way, neoliberal engineering for the recognition of minorities and the pacification of differences is challenged.

Candido, Gomes and Tanscheit: The feminist movement has been one of the most vigorous actors in street protests against the rise of the right in Latin America and the world. Some authors even define this moment as part of a "fourth wave" of feminism. In contrast, various analyzes of political scientists and traditional sociologists continue to ignore women's protagonism in the ongoing political and social processes, or when considering the group, tend to affirm a not dialogic idea with the production of gender studies. In Brazil, a recent example of this was the suggestion by some academics of causality of the increase in votes in Bolsonaro due to the contrary manifestations of women in \#EleNão (\#NotHim). To what extent do you evaluate the growth of the rightwing as a response to the actions of social movements and their continuing demands for the expansion of rights? How do you researchers on the subject consider the impact of feminist protests on recent transformations in public space?

Biroli: Feminist movements have accentuated their public presence at a time of democratic recess in Latin America and other parts of the world. Collective actors who played a central role in building post war democratic regimes, and I think especially of trade union movements, reduced their capacity for mobilization. Political parties are in deep crisis. Some analysts continue to look at what is no longer is without realizing that categories have not been sought to analyze what it is. Therefore, they connect the difficulties that the left goes through the world, for example, to what they define as "identity movements", without shame in expressing visions that an alleged "fragmentation of agendas" or "provocation to conservatives" could justify 
silencing. The \#NotHim did not bring the far right to the presidency in Brazil, nor was it able to prevent it from winning the elections. Until the end, there was a gender cleavage in voting intentions, most pronounced among the younger strata of the population, but it was unable to prevent the victory of the far right. What \#NotHim did it was put misogyny as a political problem on the streets, violence against women as a central rather than a side agenda in an election. It was a movement of strong repercussion - and was thus perceived by those who, in not spontaneous operations, set up a presentation of this movement in order to avoid the identification of more conservative sectors of society. I think of the fake images that circulated through social media, through Whatsapp. Feminist movements are actors in the most central political disputes today. Not because politics has become "identitary movement". But because they have been able to mobilize for democracy, to question the labor relations and current patterns of capture of State and life by large corporations. Could the entire feminist movement be so defined? No, of course not. But at some point did we ask this question about labor and labor movements, hoping that their legitimacy would be derived from a radical critical unity? Whoever did it, did so as a political strategy to undermine that same legitimacy.

Freidenberg: Indeed, the feminist movement is one of the most democratizing and active actors in recent Latin American history. Our feminists professors usually say that every time there has been an expansion of women's rights, a great wave of reforms and advances, there has been strong resistance and, with it, the possibility of backtracking. I think it is interesting to see that there are several repertories of action and protest (not in a single way), that the rights for which they fight are also different (in some movements they are reproductive rights and in other political and electoral rights) and the strength of alliances between the broad women's movement, along with politics and academia, is fundamental to the advancement of these rights. Meanwhile, in the countries of the South, the movement is in cyberfeminism and in the streets (Argentina, Chile), in the North (Mexico) it is fighting from social networks, lobbying and strategic litigation. Strategies are tools to achieve the objectives: to deepen the democratization of democracy. 
Gago: As I said before, I believe it is important to characterize the "against" offensive in its dimension of "reaction" to the current feminisms that in our countries stand out for three characteristics: being massive, radical and building a political agenda both at the grassroots and institutional levels. Nevertheless, as you say, there is an insistent contempt on the part of many analyses and theorizations regarding the transversal impact that feminisms are having as an antineoliberal movement. On the one hand, they try to place feminism in a thematic area, a sort of epistemic thread of political confinement, which aims not to credit or legitimize its expansive capacity, its form of political enunciation and its impact on all the dimensions of the political system and the spaces of thought.

Here there have been arguments that say that mobilizations have neither the capacity nor the effectiveness to prevent or diminish femicides, thus casting doubt on their function. That is to say, the increase in feminist mobilization is compared to the increase in crimes and a direct causal relationship is drawn, on the one hand; and, on the other, the objective is to "verify" the "ineffectiveness" of mobilization itself to counter feminicide violence.

From the discourses of psychology there is talk of a mimetic "illusion" of the strength of women, lesbians, trans and transvestites that would make them take attitudes of "empowerment" that would lead them to death. The argument mentions a "contagion effect" of the collective that, more than managing to protect the victims, exposes them even more. In a similar way, they tried to read the massive mobilization of the "Not Him" in Brazil, which wanted to blame the subsequent triumph in the polls of ultra-fascist Jair Bolsonaro. The language was also psychological-culpabilizing: the march of women and LGBTQI "awakened the monster," was also said here. The multitudinous effervescence is discredited as false, misleading and, above all, of risk (the "contagion" of a virus): it leads to trust in an experience of collective strength that would only be revealed as dangerous and illusory. Or even more: counterproductive. In other words, the strategy is twofold: blame and impotentiation. 
So, I believe that we feminists pose a fundamental question: how to explain the current alliance between neoliberalism and conservatism?

The current type of fascism, this special convergence between neoliberalism and extreme conservatism, is a policy that builds an "internal" enemy. This internal enemy is incarnated by those who have historically been considered foreigners in the "public" sphere of politics. Today the internal enemy that fascism points out is the feminist movement, in all its diversity, and the migrants, as subjects also feminized. Today's fascism reads our strength as a feminist, anti-racist, anti-biological, anti-neoliberal and, therefore, anti-patriarchal movement.

The aggressiveness of current fascism, however, cannot make us lose sight of something fundamental: it expresses an attempt to stabilize the continuous crisis of political legitimacy of neoliberalism. This crisis is being strongly produced by the transnational, plurinational feminist movement, which is currently inventing a radical mass politics precisely because of its capacity to plot transversal alliances that put into practice, in a concrete way, its subversive, transforming character, of the ways of exploitation and obedience. Alliances, as a political fabric patiently built in temporalities and spaces that are not usually recognized as strategic, formulate a new strategy of insurrection among those historically considered non-citizens of the world.

\section{The Interviews}

Flavia Biroli is a Professor of Political Science at the University of Brasilia (UnB), specialized in Feminist political theory. In 2018, she assumed the Presidency of the Brazilian Political Science Association (ABCP) until 2020, coordinating until 2018, with Marlise Matos, the thematic area Gender, democracy and public policies of the entity. Between 2009 and 2016, she was the Editor of the Brazilian Journal of Political Science and is currently Associate Editor of Politic \& Gender. She is author of several books on gender and politics, and feminist political theory, such as Autonomia e desigualdades de gênero: contribuições do feminismo para a crítica democrática published in 2013 in a partnership between UFF and Horizontes, Familia: Novos conceitos, launched in 2014 by the Perseu Abramo Foundation, Gênero e desigualdades: limites da Democracia no Brasil, published in 2018 by Boitempo.

Flavia Freidenberg is PhD in Political Science (2001) and Master in Latin American Studies (1999) at the University of Salamanca, where she was a Professor and Researcher between 2002 and 2015. Since 2015, she has been a full-time Researcher at the Instituto de Investigaciones Jurídicas at the Universidad Nacional Autonóma de México (UNAM). Since 2016, she is Associate Editor of Policy and International Relations of Latin American Researcher Review and coordinates Red Politólogas. She recently edited two books: in 2017, Cuando hacer política te cuesta la vida. Estrategias contra la violencia política hacia las mujeres en América Latina, with Gabriela del Valle Perez - and in 2018, Mujeres en la Política: 
Experiencias nacionales y subnacionales en América Latina - with Mariana Caminotti, Betilde MuñozPogossian e Tomás Dosek.

Veronica Gago is a Researcher at the National Council for Scientific and Technical Research (CONICET), based at the Instituto Interdisciplinario de Estudios de Género at the University of Buenos Aires (UBA), and a Professor of International Economics at the same institution. She is a member of the Executive Committee of RC19 - Socialism, Capitalism and Democracy of the International Political Science Association (IPSA). She is also associated with the Instituto de Altos Estudios Sociales (IDEAS) at the National University of San Martin (UNSAM), investigating neoliberalism in Latin America. Her writings were translated into several languages, such as the book La razón neoliberal: economías barrocas y pragmática popular, published in 2014 by Tinta Limón and translated into English (Neoliberalism from Below: Popular Pragmatics and Baroque Economies. Radical Americas, 2017) and Portuguese (Economias Barrocas e Pragmática Popular. Editora Elefante, 2019). With Luci Cavallero, she published in 2019 the book "Una lectura feminista de la deuda" by Rosa Luxemburg Foundation. She is a militant in the Argentine Feminist Movement Ni Una Menos. 